\title{
The Transition enabling Lifelong Learning: A thematic generalization of the national education policy 2020 in India
}

Manasa Chandramouli, ${ }^{1}$ K B Vinay, ${ }^{2}$ G V Naveen Prakash, ${ }^{2}$ N S Lingegowda, ${ }^{1}$ Madhusudhan $\mathrm{H} \mathrm{S},{ }^{3}$ Srikantamurthy Ningaiah, ${ }^{1, *}$

${ }^{I}$ Department of Chemistry, Vidyavardhaka College of Engineering, Mysore-570002, Karnataka, India

${ }^{2}$ Department of Mechanical Engineering, Vidyavardhaka College of Engineering, Mysore-570002, Karnataka, India

${ }^{3}$ Department of Computer Science and Engineering, NIE Institute of Technology, Mysore-570018, Karnataka, India 


\title{
The transition enabling lifelong learning: A thematic generalization of the national education policy 2020 in India
}

\begin{abstract}
Changes in the education policy is normally viewed with apprehension by the teachers, as it brings a change to a higher or lower level, involving novel skills of learning and running through for the improvisation of the tasks done routinely. This paper scouts the new education policy 2020 and its empirical study in which the data is investigated about the earlier policies in depth. It is a framework, helpful for developing expertise in the specific area where the teachers have often felt anxiety.
\end{abstract}

Keywords: education; policies; transformation.

\section{Introduction:}

Education is a river, which takes birth in our minds, flows to the present and meets the future at the end. The past framework of education needs to be understood well to envision the future. Briefly, it can be overviewed as a journey from the ancient to the modern period. The present education system is evolved as such from the preBritish rule, during the British rule and lastly post-independence. The education was brought as such by the Muslim invasion, which focused on the role of the kings, religious heads and its availability to the large en-mass.

\section{Change and the pedagogy:}

\section{Education in the ancient period:}

Indian civilization is one of the historical civilizations of the world. [1] India depicted a society of hierarchy after the origin of the caste system. Religion played a major role that forced education. To learn and study, the Vedic literature became the custom of the higher class people of the society (Brahmins). [2] The stages of education were wellpracticed; till the age of seven, the home was the learning place, it was for the primary learning, then from eight to sixteen, it was schooling after a holy ritual called 
upanayana, a ritual compulsorily practiced in Brahmins.[3] At this stage, the education was also extended to 12 years and the whole education changed according to their respective caste. And studies were in the universities led by a kulapathi. Hence the primary education at home, secondary education at school and finally advanced learning at the university, a way was created. There was no rule that women should not undergo education but in name of customs, they were locked behind doors.

Later the world of Brahmins ended and led way to other religions like Jainism and Buddhism. Then the education was equal to all and was not stressed only on Vedas. A sign of development was seen. Soon there were some schools developed for the education of children despite caste, creed, and sex. The credit is to the throne holders of the Nanda dynasty, due to their attribution to the education, Takshashila- a university, gained worldwide attention. [4] At this time education was limited to medicine, law and fighting skills. Later by the invasion of the Guptas and Harsha dynasty, education took a new lead towards science. [5] It was noticed that India grew up with temples and they were the sign of the growth of education. But religion governed education. Girls still were behind the doors. Whereas vocal education was mainly their learning. The education policy was just a glimpse of the socio-economic condition of the society. [6]

Another era, witnessed the evolution of pathshala and madrasas, bringing out pandits and moulvis respectively. [7] Girls now had a narrow gate opened for education in schools. The demerits of the native system paved the way for new education policies in India by the British.

\section{Change and the pupil:}

\section{Education under British:}

The desire for the colonies was the basement of colonial education. [8] The English language came to popularity. The Christian missionaries also took their hand in 
the spread of education. East India Company was further forced to take up the former task. Many reform movements also worked for the spread of education. The education policy was framed according to the needs of the administrative colonies and to date, education is only according to the needs of the government. In the last fifty years, India has witnessed huge growth as well as several ups and downs in the education system. Then came into push Indian literature, where politics played a vital role. The Indian National Congress then started their protest to abolish the unrest of education policies due to politics. Education research was being promoted after the establishment of the Indian Institute of Science. [9] It turned the policy of free and compulsory education. The education policy reflected the debate between the Indian and British governments. The British wanted to stop education as it would make people aware of the politics, as Indians wanted people to get educated to strengthen the base of the freedom movement.

\section{Possibilities of the evidence-based practice:}

Education after independence: Post-independence, the education policies did not come to force. The importance of different levels of education was stressed, education was further classified into secondary and university levels showing the importance of policies. Promises made to people during the freedom movement took their turn to reform or create a fresh policy of great contribution. The country had full liberty to change the education policy and the state policies now enforced free and compulsory education up to the age of 14. [10] The changes in the policies of secondary and higher education were now made according to the needs of independent India. The theoretical concepts were now focused to have a practical basis.

A university education system was established in 1948, headed by Radhakrishna, to uplift the university education system to meet the present and future needs and the reorientation of the Indian education policy took a facelift. To overcome 
all the odds against the practices of society, education was believed to be the strongest weapon. [11] Promoting higher education was the main objective. The economy should not be a hindrance to education, and for this Nehru stated that political independence should be transformed to economic independence, a proper way of efficient democracy [12] and then occupational institutes were promoted.

Now a secondary education commission (1952) headed by Dr. L. S. Mudiliar reorganized the objectives and aims to owe to the need of the employment situation to which the need for Technical education was stressed upon. [13]

Education commission (1964-66) under the guidance of D S Kothari framed an education policy in 1968 , the necessity of the real change in the education policy was highlighted to meet the issues that were faced by the country in different areas. The three main aspects came to light;

1. Internal transformation: Education must be related to life, aspiration and needs of the people. Education can be made a magnificent tool only by these means. Science education was emphasized. Social and national services were enforced. National unity was propagandized. Not only full-time, but even part-time education was also encouraged.

2. Quality improvement: A standard was marked for the utilization of the facilities progressively. A correct change in the teaching techniques was encouraged. Development was the main goal.

3. Expansion of education facilities: Adult literacy was to be achieved. Primary, secondary and higher education was given great importance. Yet many ideas and proposals with the need of importance were not implemented. [14]

It was the utmost grip on the administration of higher education when the Banaras Hindu University Enquiry Committee was appointed in 1969. [15] The 
education system was subjected to mending in the year 1977, after the defeat of Congress in adding it to the concurrent list from the state list. Now came into emergence, the Gandhian model as a role model, and this education policy did not go well with the government. [16] A way for Draft National Policy of Education was framed in 1979, claimed to possess the complete ability of the individual under their intellectual talent. [17] emphasis on human values was also introduced. Education was framed in strengthening unity, secularism, socialism and democracy, and this was believed to be the pride of the country in the future. Scientific thinking and inculcating moral values were emphasized. Gandhi's "basic knowledge" was all in the air. Knowledge should bring out the potentialities of the people serving as a bridge for the development to overcome social-biased discrimination. Directive Principles of the constitution framed compulsory education up to the age of 14 . The curriculum was framed as such to encourage a wide zone of learners. To encourage education, free uniforms, textbooks, mid-day meals were supplied. [18] Extra care was given to up bring education in Scheduled caste and tribe, and also in girls. A common school system provided a quality education.

The revised Minimum Needs Program was introduced to encourage adult education, which was believed to develop an interest in self-education. A strong foundation for those who wanted to pursue higher education and fully with comprehensive contents for those who cannot pursue education further was the main aim of secondary education. Higher education is aimed at national development. Several aspects of agricultural education, physical education, medical education, reforms in the examination, teacher's education and their role came to light. More or less this education policy matched those with the previous ones besides the adult education system. The post-independence education system was just satisfactory. Finally, the 
Indian education system is showing off differences in socio-economic forms. Achievement of education is still a dream for many, universalization is not effective. The Indian education system is weighed low both qualitatively and quantitatively. The competent growth and technical development have now forced the policymakers to throw light on the same and strive for it in the present educational systems. On this note, "Challenges of education: A Policy Perspective" in 1985 was released as a document on the educational development to frame a policy which can meet the needs of the new challenges remembering the before education. [19] This has also stated that India has made great progress in the count of the educational institutions and educational programs. The count of children gaining an education has progressively increased, especially the count about girls. But yet we are many steps back from achieving the goal. Dropout from education was increasing their count and it was also foreseen probably that India would witness the highest illiteracy rates by 2000AD. [20] Provision of primary facilities was stressed at primary and middle schools. Even after 40 years of independence, India was still lagging in education. The education policy is over-sighted by the political games. People's needs are to be counted, as their demands remain the same in ancient and post-independence time and thus inequalities have raised to their heights in society. Probably it results from the education policy. The distance learning and Open University systems evolved contributing to the encouragement of higher education. In a true sense, it was understood late in the 19th century that education is not knowledge, it is the training of the mind to gain wisdom. Though many attempts are made to improve, the modern education system is still a nightmare for policymakers. Dropouts are still a matter of concern. A serious consequence will be nailed if the education system is not reformed, as we are failing to respond to different opinions. Yes after 1968 by Indhira Gandhi and 1986 by Rajiv Gandhi, [21] it is now in 2020, by 
Narendra Modi the education policy is propagated. [22] Finally, approval to the new education policy from the $10+2$ system to the $5+3+3+4$ system is approved. From times immemorial India has been the place of learning. There are also great efforts taken to develop higher education in India to bring up an educated country. The government of India is continuously striving for higher education, now trying to do the effective transformation in the policies and thus we have this new education policy, to work at its fullest.

\section{The structure of National education policy 2020:}

\section{Vision:}

The main vision of the education policy 2020 is to develop a system that can provide good quality of education to all. It has also visioned to develop respect towards the constitutional rights and duties and enforcing values which can bring one's contribution defining their role in changing the world. In total instilling the responsibility of becoming a global citizen.

\section{Principles:}

The principles involve curriculum covering the same for the diversity of people, involving equity in all the education concerns, open to the community, make education an understanding mode rather than trivial learning only to score in examinations, identifying the capabilities, developing creative and critical thinking, use of technology in teaching and continuously involving in research.

\section{Universal access to early childhood care and education:}


For children from 3-6 years have access to utilize free education under Anganwadi /preschools and further children of age group 6-8 years to the primary school implemented under the HRD, Women and Tribal ministries.

\section{Ensuring education at all levels:}

Bringing dropouts back to school is the main agenda, the creation of an alternative learning center is visualized, provides learning in various ways, both formal and nonformal ways of education to be encouraged. Building more schools is also cited. The outcomes of learning to be concentrated, making it more presentable.

\section{Outcomes are foreseen:}

Universal access to step from primary to secondary education, justice in education, and bring back the dropouts, making children continue up to secondary education, learning outcomes should reflect achievements, assessment and teaching skills to be updated to compete with 21 st century, provide easy access to learning resources, the language barrier should be overruled, universal standards for both public and private sectors.

\section{Transforming curriculum:}

The new structure of pedagogical over the existing one is $5+3+3+4$, over the $10+2$ years. It clarifies that 5 years is spent in preschool, later 3 years is the middle stage where experimental learning is given prominence, further 3 years of progressive classroom learning associated with the interaction, which is also activity-based and the last 4 years is for the creative thinking, which would have developed and enhances the flexibility to the candidate to take over the subject of his/her choice. The National Council of Educational Research and Training (NCERT) is upheld with the responsibility of designing the framework which will be in support of the research aligned with best practices. Logical thinking, outdoor and indoor games, problem- 
solving, drawing, painting, puzzles, drama, music and many more to be an integral part of learning. A module is prepared which is play-oriented for 3 months by NCERT for grade 1 students.

\section{Education is learning:}

Under this policy it is aimed to develop curiosity, logical thinking and problem solving, arts, craft, music, relationship with nature, colors, shapes, alphabets, numbers, play and discovery-based learning, ethics, self-identity, teamwork and collaboration, good behavior and emotional development. To promote the foundational skills, 3 months of play-based school will be set up, with a focus on early reading, writing and mathematics. It is also noticed to enhance the high-quality learning with enormous resources, by developing digital library along with school library.

\section{Curriculum:}

A load of the curriculum will be shed off, just concentrating only on the core essentials, critical thinking, interactive classes, and experimental learning and this change is promoted to focus on skill orientation and to reduce the rote system of learning. The transformation is expected due by 2022. Outcome-based education to be implemented. Integration of the subjects to be practiced during the design of the curriculum to develop scientific temper and having no bars between curriculum, co-curriculum and extracurriculum learning. Language should not be the barrier and also digital learning is emphasized. Diksha platform is taken for the digital content of the textbooks. States are up to the line in adding their contents following NCERT guidelines. Gender sensitivity to be an integral part of the curriculum.

\section{Wellbeing:}


Annual health checkups are mandatory. Counselors to be hired. Proper infrastructure to build to meet the needs of disabled students. Health and good nutrition practices to be imbibed in students, also monitoring their mental health. The weight of the school bag to be reduced. The school should provide a good caring ambiance and practice inclusive culture. The innovative teaching-learning process to be well balanced to support the good health of the student.

\section{India's future:}

The future of the country is seen in computational thinking, a hope of increased emphasis on mathematics, problem-solving, contemporary subjects like artificial intelligence, design thinking, holistic health, organic living, environmental education, global citizenship education.

\section{Growth of knowledge in future India:}

The knowledge empowers its way by documenting videos on the inspirational luminaries in science, by providing a framework for logical thinking at a young age, by making them know the effects of malpractices, by instituting human values, by practicing good health routine, by developing scientific temper, by covering all the systems of Indian knowledge, by imbibing in them the route of travel from ancient India to modern India and also focusing the future, by showcasing the ill effects of alcohol, tobacco, etc.

\section{Examination:}

The grading system will be based on outcome-based education. A clean assessment at grades-3, 5, and 8 will be done to monitor the schooling system again just for developmental purposes. The learning will be allied in assigning with real-life situations 
besides the rote way of learning. By 2022-23 the teachers will know this new assessment method. A standard norm will be given by Performance Assessment, Review, and Analysis of Knowledge for Holistic Development (PARAKH) National Centre. The attainment levels will measure the standard of the curriculum. Board exams at 10 and 12 grade will be made student side testing their core capacities, where the students must take up both objective and descriptive examination. Each subject will be at two levels; initially, it is started with mathematics. The system for the examination will be guided by NCERT in association with the State Council of Educational Research and Training (SCERTs'), Board of Assessments, and PARAKH. The National Testing Agency sees that it provides a high-quality aptitude test which will hold off the coaching classes. Mainly an Artificial Intelligence (AI) system to track the continuous progress of the students.

\section{Progress card:}

The progress card is designed in grading multidimensional reports of the student progressively collecting reports from all the fields in which the student had been involved including self-assessment, peer assessment and finally teacher assessment. AIbased software will help the student to take the correct career decision.

\section{The language game:}

The language will be the mother tongue/ local language used for teaching at least till grade 5. A fun project-"Languages of India" should be taken up by each student. The languages to be studied will be decided by respective states, as all classical languages will be present as optional.

\section{Schools:}


One government school will be paired with one private school. Integrating shared resources, shared teachers and schools will be put forth. The governance of the schools has to resource with good building plans- both short and long-term plans. Bal-Bhavan, Samajik Chetna Kendras will be promoting career, art-related activities imparting the importance of social, intellectual and voluntary activities.

\section{Qualified teachers:}

By 2030, it will be made compulsory that a teacher should have a qualification of 4 years integrated Bachelor of Education (B.Ed) or two-year B.Ed with already a Bachelor's degree or one-year B.Ed., who has complemented an equivalent of four years integrated course or obtained a master's degree to teach for local schools. The education of teachers will move on to be multidisciplinary and an Open and Distance Learning (ODL) mode of teaching to be applied for students in remote areas. The B.Ed programs will enforce all the teachers to learn new teaching techniques, teaching children with attractive methods will be showcased, new evaluation for multilevel teaching will be adopted. Persons can do short teacher education programs, available at Behaviour Intermediary Target And Evaluation (BITE), District Institute for Education and Training (DIET), who can later avail an option of being hired for teaching at schools as 'master instructors', mainly to encourage the locals professionally. A new curriculum framework for teacher education will be framed by 2021. A multidisciplinary program to be formed. National Testing Agency (NTA) testing for B.Ed. Strict actions will be taken upon those institutions that give out substandard teachers. National Higher Education Regulatory council will also tap for teacher's education. The Teachers Eligibility Test will be strengthened at all stages. The mentoring by senior or retired faculty will be set up by National Mission. A merit 
system for the admissions of 4 years integrated B.Ed course will be formulated. Ph.D. awarded faculties are also strictly advised to complete a module on teacher's education.

\section{Appointment of teachers:}

Selection will be based on The Teacher Eligibility Test (TET's). Predicting the need for technologically supported faculty, subject wise for the next two decades. Only certified teachers to teach the disabled students, and they will be in the synergy between the National Council for Teacher Education (NCTE) and Rehabilitation Council of India (RCI). An online mode of transfer ensuring complete transparency. During the recruitments, a demonstration class along with the eligibility test score will be counted. It is set as NCTE will be working under General Education Council.

\section{Growth of teachers:}

National Professional standards for teachers to be provided by 2022. Under which career growth will be promoted providing good workspace at school, by which teachers can select the mode of pedagogy in classroom teaching and each state is advised to forecast the teacher's requirement for the technology-based education system. Teachers will also be permitted to chair leadership positions in academics. The professional growth will be tracked through 50 hours of continuous professional development, and a merit-based tenure track system.

\section{Reducing the gaps:}

The students will be encouraged to take up education, despite sex, caste, creed. There will be no geographical restrictions. Disability to be removed as a barrier to education. Socio-economic problems to be conditioned not to affect the education of the student. These basic strategies will reduce the gap in schools and much attention is focused on this. 


\section{Ensuring the right to education:}

Enrollment and attendance will be made compulsory. Tribal groups will be fetched to educate themselves through different mechanisms. The outcomes of education in SC/ST/OBC students will be counted. Special education zones to be created for large socio-economic disabled groups. Scholarship and fee waivers for the former class of people to be encouraged. Counselors to be appointed in schools. The Kasturba Gandhi Balika Vidyalaya (KGBV's) to be extended till grade 12. Framing of policies targeting girls to promote their education with safety.

\section{Children with special needs:}

This class of children will be trained to learn the Indian sign language, and also will be provided with alternate schools that can provide alternative pedagogical methods and also with assistive tools, along with their parents. And teachers are to do special certificate course to train this class of students. These children will be aligned with regular schools.

\section{Vocational education:}

Skill gaps to be recognized and provided with local opportunities are the main focus. Both Open and Distance Learning modes to be encouraged. By 2050, at least we can count on $50 \%$ of learners having exposure to vocational education. An easily accessible "LokVidya" will be available to the students. A framework will be there to attain National Skill Qualification for each discipline vocation. All students from grades 6 to 8 will have practical experience with the local vocational experts.

\section{PARAKH:}

PARAKH, Performance, Assessment, Review and Analysis of Knowledge for Holistic development will be guiding and conducting State and National Achievement Survey, 
monitoring the learning outcomes in the country, which is abided by the standard norms and guidelines for assessment and evaluation set by them.

\section{The special talent of students:}

The student will be encouraged to get and achieve more other than the school curriculum. Different clubs where students can work on projects to be developed in schools. Encourage students to participate in competitions across the country. B.Ed programs to offer special education to educate children with a special talent. Local language and rural area involvement is considered to allow wide participation. The use of technology in the $21^{\text {st }}$ century is advised. NCTE and NCERT will be setting guidelines for the same.

\section{Digital education:}

Pilot studies to be widened. E-learning platforms to be familiarized. Involvement of Information and Communication Technologies (ICT) tools in effective teaching to be noted. Digital content for easy access to be prepared. Blended learning with model making to be concentrated. Divyang and other disadvantaged students to get access to education by the mentioned means.

\section{Lifelong learning:}

Adults know community participation and also the new technologies. The adult education centers to collaborate with public institutions are also planned well. Satellitebased TV channels to be incorporated for effective learning in adults. Government to take initiative in constructing adult education centers that have access to $\boldsymbol{a}$ digital library, ICT-equipped libraries. Adult education is addressed mainly for fundamental literacy and numeracy, to develop life skills critically, to develop vocational skills, to gain basic education, or to continue education. 


\section{Implementation of the policy:}

Early childhood education is done in two phases where phase 1 is a preprimary school for one year with 3 months of preparatory module for class 1 and phase 2 is an expansion of one-year preprimary school by primary schools. New curriculum to be designed by 2021-22 for class 9 , by 2022-23 for class 10 , in which new board exam pattern will also be viewed. And in 2023-24, implementation of a new curriculum and assessment for class 11 will be introduced, by 2024-25, the class 12 curriculum with a new exam pattern will come to light. By 2025-26, 50\% will have been exposed to vocational education. 2029-30 will witness the multidisciplinary education being practiced. 2040 will be the check date for the policy working.

\section{Conclusion:}

This paper attempts to add more to the existing anxiety or may also be felt as a difficulty for the conventional policy of education. It is not just restricted as an investigation in increasing the knowledge about the education policy but might be proposed as an unproblematic transfer of the improvements in all contexts regarding education at the foundational level. It may also lead to the improvement of the pedagogical practices by promoting teacher research. It is not the end of the count up, it has just begun, a far way to go, literacy to grow and also make the country progress. With the hope of this education policy would bring good literacy rates in the country, which can review the implementation of the policy under the target set for every action.

\section{References:}

[1] Wolpert, S., \& Wolpert, S. A. (2006). Encyclopedia of India: KR. Charles Scribner's Sons.

[2] Smith, F. M. (1996). Classifying the Universe: The Ancient Indian Varṇa System and the Origins of Caste. 
[3] Sutton, D. R. (2018). 'So called caste': SN Balagangadhara, the Ghent School and the Politics of grievance. Contemporary South Asia, 26(3), 336-349.

[4] Pandya, D. R. N. (2014). Indian education system-a historical journey. Education, 3(3).

[5] KANT, R., \& SINGH, B. Education System in Ancient Indian.

[6] Levin, B. (2003). Approaches to equity in policy for lifelong learning. Education and Training Policy Division, OECD. Paris: OECD.

[7] Radhika Kapur. (2018). Education in the Medieval Period, 1-12.

[8] Preethi. (2016). Colonial Codification of Education in India until 1920, 1-18.

[9] Jayakanth, F., Minj, F., Silva, U., \& Jagirdar, S. (2008). ePrints@ IISc: India's first and fastest growing institutional repository. OCLC Systems \& Services: International digital library perspectives.

[10] Mondal, A. (2017). Free and compulsory primary education in India under the British Raj: A tale of an unfulfilled dream. SAGE Open, 7(3), 2158244017727037.

[11] Kirloskar-Steinbach, M. (2018). Representing Indian Philosophy Through the Nation: an Exploration of the Public Philosopher Radhakrishnan. Sophia, 57(3), $375-387$.

[12] Viswanathaiah, K. V. (1965). Jawaharlal Nehru's Concept of Democratic Socialism. The Indian Journal of Political Science, 26(4), 91-99.

[13] Mudaliar, A. (1953). Report of the secondary education commission (October 1952-June 1953). Government of India, Ministry of Education, Madras.

[14] Kothari, D. S., \& Chairman, A. R. (1967). Report of the education commission 1964-66. New Delhi, National Council of Educational Research and Training.

[15] Banaras Hindu University Inquiry Committee. (1969). Report of the Banaras Hindu University Inquiry Committee (Gajendragadkar Committee) (January-July 1969).

[16] Szasz, M. C. (1977). Federal boarding schools and the Indian child: 1920-1960. South Dakota History, 7(4), 371-384.

[17] Little, A. W. (2010). Access to Elementary Education in India: Politics, Policies and Progress. CREATE Pathways to Access. Research Monograph No. 44.

[18] Khera, R. (2006). Mid-day meals in primary schools: Achievements and challenges. Economic and political weekly, 4742-4750.

[19] INDIA, E. Challenges of Education: A Policy Perspective. 1985. New Delhi, the author. 
[20] Chauhan, C. P. S. (1990). Emerging priorities in Indian education. Education and Society, 8(1), 12-20.

[21] Singh, P. Trends and contemporary provisions in Government Spending on Elementary Education in India: Inquiry on Insufficiency of Funds.

[22] Sharma, M. (2016). Narendra Modi and the new education policy: retrospection, reform and reality. Journal of Asian Public Policy, 9(2), 140-153. 